\title{
LEARNING BY ACCIDENT, LEARNING BY DESIGN: THINKING ABOUT THE PRODUCTION OF SUBSTANTIVE KNOWLEDGE IN THE LRW CLASSROOM
}

\author{
Leonore F. Carpenter* and Bonny Tavares ${ }^{* *}$
}

\section{INTRODUCTION}

As law teachers, we understand that simulation-based courses like Legal Research and Writing ("LRW") provide critical avenues for students to learn lawyering skills. We want those courses to be rigorously designed, have clearly delineated learning outcomes, accurately assess student learning, and provide opportunities for our students to become further engaged-maybe even inspired-by the idea of law practice.

As law teachers, we would also prefer that student effort is in no way wasted by obtaining knowledge in a simulation course that will never be useful to them. But that's a challenge in the context of simulation-based courses, where acquisition of knowledge of the issue area chosen as the subject of the simulation is not the primary purpose of the course. How can we do a better job of designing LRW and other law school simulation courses where the substantive legal knowledge gained by our students has value to them, regardless of career path, and serves the law school's goals of producing lawyers who are knowledgeable, ethical, and skilled? This is the problem that this article seeks to address.

As anyone who knows an American schoolchild is aware, the lower elementary grades tend to be about learning how. Schools save the substanceheavy stuff-the history, science, and social studies-for the upper elementary grades, so that we can make room for younger children to develop the basic literacy and math skills they will need to make sense of substance later on. ${ }^{1}$

\footnotetext{
* Associate Professor of Law, Temple University James E. Beasley School of Law. The author wishes to thank her co-author Bonny Tavares for her intelligence, insight, hard work, patience, and writing talent, and (more importantly) for just being a terrific human. The author also thanks Professor Rachel Rebouche and the faculty participants of the Temple Law Writers' Workshop for incredibly thoughtful and detailed comments and suggestions on earlier drafts. She also thanks the many education experts who provided guidance when this project was in its infancy, including Dr. Susan H. McLeod, Professor Kristen Murray, and Dr. Kira Baker-Doyle. And of course, the author thanks her wife, Tiffany L. Palmer, for all of the other stuff.

** Assistant Professor of Law, Temple University James E. Beasley School of Law. The author wishes to thank her co-author Lee Carpenter for sharing her ideas, and for her brilliance, creativity, humor, and hard work. The author also thanks her colleagues at Temple who helped to workshop this article, and especially her LRW colleagues-Susan DeJarnatt, Mary Levy, Ellie Margolis, Kristen Murray, Robin Nilon and Kathryn Stanchi. A special thank you to our former LLM students, Associate Professor Brian Murray of Seton Hall University School of Law, and Chicago-Kent School of Law Professor Cody Jacobs, who taught their students using the LRW assignment discussed in this article and contributed significantly to its development. And finally, a big "thank you" to my daughter, Haley Simone Tavares.

${ }^{1}$ See DAVID ACKeRMAN \& D.N. Perkins, Integrating Thinking and Learning Skills Across the Curriculum, in INTERDISCIPLINARY CURRICULUM: DESIGN AND LMPLEMENTATION 79-81 (Heidi Hayes Jacobs, ed., 1989) ("What is most striking in the prevailing approach to skills and content is the
} 
Of course, we know, from watching schoolkids navigate those lower grades, that the skills/substance divide is not quite as neat as it sounds. After all, our kids can't learn to read unless they are learning to read about something. For those of us who are caregivers, this can result in some rather surprising revelations about the items of information that our kids have picked up in the process of learning basic skills like literacy. For example, one afternoon, one of the authors' children-who was in third grade at the time-came home and began to chat, quite unexpectedly, about Japanese culture generally, and about the US nuclear bombing of Hiroshima and Nagasaki specifically. These topics seemed highly unlikely to be the subject of casual conversation among eight-year-olds, or even the topic of a television show geared toward that age bracket. When asked where she'd gained this newfound knowledge, the girl explained that her reading group had been assigned a book whose protagonist was a World War II-era Japanese girl. She'd found the book riveting, and had, in the process of reinforcing her developing literacy skills, amassed a bit of knowledge of Japanese culture.

For parents of younger children, this is often the norm. Our children come home from school packed full of information that is sometimes universally useful and intentionally transmitted, but also sometimes seemingly arbitrarily selected, and learned incidentally in the process of developing a skill. Usually that skill is either reading comprehension (in the instance described above) or research and report writing. ${ }^{2}$ For the purposes of this article, we will call this information "incidental declarative knowledge." We use the term "incidental" to indicate that the knowledge itself is not the point (either primarily or at all) of the instruction, and can be swapped out with another body of knowledge with little effect on the desired learning outcome. We use the term "declarative" to connote formalized, substantive knowledge, as opposed to the acquisition of a skill-in essence, "what" knowledge as opposed to "how" knowledge. Thus, "incidental declarative knowledge" is a body of formalized knowledge that is learned in the service of skills development, but which is interchangeable with other bodies of knowledge that can serve the same pedagogical purpose. ${ }^{3}$

dichotomy between elementary and secondary education. In elementary schools, skill teaching, notably the '3Rs,' is prominent, while the content areas of science and social studies get short shrift. The skill teaching orientation is so pervasive that it engulfs whatever it comes in contact with. Thus, basal readers run students through a gauntlet of literature skills in addition to regular reading skills, social studies emphasizes map skills, and proponents of higher-level thinking see their elevated visions transformed into still more skills lists. Advocates for stronger content emphasis are rebuffed by the argument that young students must focus on 'the skills' so they can handle the massive amount of content awaiting them in the years ahead.").

${ }^{2}$ In the course of learning basic internet research and report preparation skills, our children have developed expertise in a strange and disparate array of substantive areas, including: the nation of Italy, chin-strap penguins, the Choctaw Indian Tribe, the State of Utah, and the biography of astronaut and doctor Mae C. Jemison.

3 "Incidental learning" is an established term in education literature that is used to describe learning that occurs as an unintended byproduct of learning something else. See generally Sandra Kerka, Incidental Learning: Trends and Issues Alert 18, ERIC CLEARINGHOUSE ON ADULT, CAREER, AND VOCATIONAL EDUCATION (2000) https://files.eric.ed.gov/fulltext/ED446234.pdf. The concept of 
Later in life, the educations of students who are not tracked toward vocational training shift from a highly skills-based curriculum to one that is increasingly geared toward the acquisition of formalized knowledge in designated subject areas. ${ }^{4}$ By high school and college, those students-particularly those in liberal arts majors-are learning some skills (like higher-level writing courses, generalized critical thinking, labs in science classes and studios in arts courses). But by and large, college prep-tracked high school students and college students are becoming accustomed to an educational system structured around bodies of formalized, substantive knowledge-Early American History, $19^{\text {th }}$ Century Russian Poetry, Geology for Non-Majors. The phenomenon of incidental declarative knowledge recedes into the background as liberal arts educations become more narrowly focused and less grounded in skills development. ${ }^{5}$

Law school, however, reverses the trend. Thanks in part to concerted efforts to recognize that law training must incorporate the how of lawyering as well as the what of legal doctrine, ${ }^{6}$ American law schools now extensively and mindfully incorporate skills training and so-called "experiential learning" into their curricula. ${ }^{7}$ In the second and third years, clinical programs abound, as do trial advocacy training programs, negotiation simulations, and other skill-building opportunities. And most strikingly, almost every law school now features a firstyear legal research and writing course that uses simulated client problems to

\footnotetext{
"incidental knowledge" is related, in that it also refers to the acquisition of knowledge in the course of learning about something else. But it is also a little bit different, in that "incidental knowledge" refers to the body of knowledge itself, and not the process of acquiring it. It is also different in that education literature usually refers to "incidental learning" in the context of learning a skill in the context of learning something more formal. In this article, we will refer to "incidental declarative knowledge" in almost the opposite context-the acquisition of formal, substantive knowledge in the course of acquiring a skill.

${ }^{4}$ ACKERMAN \& PERKINS, supra note 1 , at 80 . ("In the secondary schools, subject matter content dominates, and the prevailing assumption is that students have already learned basic skills.")

${ }^{5}$ Of course, critical thinking is a very important skill, and one that is ostensibly instilled in students in the course of a liberal arts education, but here, we turn our attention to more concrete skills.

${ }^{6}$ Advocates for greater emphasis skills training in legal education found a potent champion in the Carnegie Foundation's 2007 report, Educating Lawyers: Preparation for the Profession of Law (hereinafter "Carnegie Report"). See William M. Sullivan et al, Educating LaWyers: PREPARATION FOR THE PROFESSION OF LAW 6 (2007) ("Most law schools give only casual attention to teaching students how to use legal thinking in the complexity of actual law practice. Unlike other professional education, most notably medical school, legal education typically pays relatively little attention to direct training in professional practice. The result is to prolong and reinforce the habits of thinking like a student rather than an apprentice practitioner, conveying the impression that lawyers are more like competitive scholars than attorneys engaged with the problems of clients. Neither understanding of the law is exhaustive, of course, but law school's typically unbalanced emphasis on the one perspective can create problems as the students move into practice.").

${ }^{7}$ In fact, they are required by the ABA to do so to retain accreditation. See ABA Sec. of Legal Educ. \& Admissions to the Bar, 2017-2018 Standards and Rules of Procedure for Approval of Law Schools, Standard 303 (2017) (mandating that accredited law schools require that students complete a course on professional responsibility, first-year legal writing, upper level legal writing, and one or more experiential courses).
} 
introduce nascent lawyers to the skills needed to research, analyze, and communicate law. ${ }^{8}$

It is in these law school simulation-based skills courses that the curious question of incidental declarative knowledge again appears. As in early elementary education, skills learners in law school cannot avoid incidentally learning a body of substantive knowledge in the service of learning the targeted skill. One cannot learn to argue a motion, write a brief, or research a legal problem that is not about anything, any more than one can learn to read a book that is not about anything. Law school simulation-based courses can be-and are-designed using a practically endless selection of substantive legal issues. Thus, the incidental declarative knowledge acquired in the course of learning a skill in law school may well be completely superfluous to a student's other learning goals. However, the literature on LRW teaching specifically and simulation-based courses generally has yet to frontally address this issue

The authors of this article are both professors who teach first-year Legal Research and Writing at Temple University's Beasley School of Law. After several years of teaching from more traditionally designed LRW problems, the authors set out to develop a problem that directly addressed the issue of incidental declarative knowledge acquisition. As this article will explain, we eventually developed a problem based upon a professional responsibility issue, and have been very pleased with the results. We write this article to provide a more solid framework for talking about this problem design issue, and to suggest using professional responsibility issues as one possible solution. The authors approach the incidental declarative knowledge problem from the perspective of LRW, but our observations will hopefully prove useful in any simulation-based course where doctrine is incidentally taught in the service of skills training. Part II of this article presents a new way to think about knowledge production in the law school context. First, this Part orients the reader to the long-standing discussion over the traditional dichotomy ${ }^{9}$ between "skills" and "doctrine" in the organization of American law schools. The authors agree with others who have characterized that dichotomy as simplistic and essentially false. Instead, the authors suggest that readers think about knowledge production in law school as being divisible into "practical" knowledge and "declarative" knowledge, and to further consider that the production of knowledge is sometimes deliberate and sometimes incidental to other learning goals. Part III discusses the design of first-year LRW courses, and describes the ways in which LRW professors have traditionally been instructed to think about the design of first-year LRW problems. The authors note that, with limited exceptions, literature on LRW pedagogy has not really addressed the difficulty in accounting for declarative knowledge production in LRW classrooms. This Part

\footnotetext{
${ }^{8}$ As noted in supra note 7 , the ABA requires law schools to offer a mandatory first-year legal writing course.

${ }^{9}$ See e.g. Susan E. Thrower, Teaching Legal Writing Through Subject Matter Specialties: A Reconception of Writing Across the Curriculum, 13 Legal Writing: J. Legal Writing InSt. 3, 17 (2007) (discussing classroom efforts to promote the integration of skills and substance as efforts to disprove "the falsity of the dichotomy between skills and substance").
} 
also considers the few approaches to mindfully considering the teaching of doctrine in LRW that have been tried in the past, and points out advantages and disadvantages to the described strategies. Part IV introduces the authors' proposal to use professional responsibility as a potential solution to the incidental declarative knowledge problem in LRW and other simulation-based course design. This Part describes the authors' approach to the issue, and the specific problem design that the authors developed. Part V concludes this article.

\section{TYPES OF KNOWLEDGE PRODUCED IN THE LAW SCHOOL CLASSROOM: THINKING BEYOND THE "SKILLS/DOCTRINE" DIVIDE}

Part II of this article seeks to briefly orient the reader to the long-standing discussion over the traditional dichotomy between "skills" and "doctrine," and to then provide an alternative framework for thinking about these concepts. The framework that we suggest takes into account both the type of knowledge produced, and also whether that knowledge is produced on purpose, or incidentally.

Historically, law teachers have thought of legal education as essentially separable into two categories of knowledge-"skills" and "doctrine," which in turn represent the theorized separation between "legal theory" and "legal practice."10 The distinction between legal theory and legal practice itself has a long and complex history, which is intertwined with the legal academy's late-1800s shift from apprenticeship programs and trade schools to the more formalized, academic method of law teaching first pioneered by Harvard and its famous dean, Christopher Columbus Langdell. ${ }^{11}$ By the early $20^{\text {th }}$ century, the Langdellian "academic" model had become not only a descriptor of a certain approach to legal education, but also a proxy for a high quality of legal education. ${ }^{12}$ Thus, the Langdellian approach to law teaching; i.e., the "case method," which involved Socratic questioning, use of appellate cases as primary texts, and foregrounding of the theoretical over the practical, was the prevailing influence on legal education for most of the twentieth century. ${ }^{13}$

\footnotetext{
${ }^{10}$ See Leigh Hunt Greenshaw, "To Say What the Law Is": Learning the Practice of Legal Rhetoric, 29 VAL. U. L. REV. 861, 862 (1995) (describing "the conventional dichotomy between theory and practice").

${ }^{11}$ See Olufunmilayo B. Arewa et. al., Enduring Hierarchies in American Legal Education, 89 IND. L.J. 941, 945-946 (2014).

${ }^{12}$ See Arewa et al, supra note 11 , at 946-954 (describing how, at the turn of the $20^{\text {th }}$ century, AALS and the ABA promoted the Langdellian law school model as the ideal to which all law schools should aspire).

${ }_{13}$ See generally W. Burlette Carter, Reconstructing Langdell, 32 GA. L. REV. 1, 96-107, 135-139 (1997) (arguing that Dean Christopher Columbus Langdell's original vision was the integration of practical and theoretical training and the hope that students trained by his "case method" would go forth and change the law itself).
} 
However, in recent years, scholars-particularly those in the field of legal research and writing-have recognized that the dichotomized framework of law school instruction has major drawbacks, and so have launched critiques of that framework. Those critiques have taken a number of different forms.

The primary critique of the skills/doctrine divide has been that it simply is wrong; that it paints a simplistic and inaccurate picture of the way that law is taught and learned. Critics have pointed out that the traditional dichotomy underestimates the degree to which skills courses teach doctrine and the degree to which legal skills are imparted in traditional doctrinal courses. ${ }^{14}$ Thus, the categorical boxes into which we tend to shove law courses do not serve us well; instead, they blind the legal academy to the actual learning activity that takes place in our classrooms every day. ${ }^{15}$

Critics have also noted that the maintenance of categorical barriers between courses thought of as "skills" and those thought of as "doctrine" acts in opposition to new goals for legal education. Specifically, critics point to the MacCrate and Carnegie Reports' emphasis on better integration of skills training across the curriculum, and then observe that the more rigidly the skills/doctrine hierarchy is enforced, the less likely legal education will be to achieve the aim of seamless integration of skills teaching in traditional "doctrinal" courses. ${ }^{16}$

The authors agree with the skills/doctrine critics. It is certainly true that some courses tend to teach more toward the "how" end of the spectrum (i.e. the way that lawyers get things done) while others focus more intently on the "what"

14 "The lines that have been drawn between 'doctrinal' and 'skills' courses are, in actuality, more a matter of perception than reality. If we were to deconstruct the pedagogical goals in both of these types of courses, we would find that they have as many similarities as they have differences." Amy E. Sloan, Erasing Lines: Integrating the Law School Curriculum, 1 J. Ass'N LEGAL WRITING DIRECTORS 3, 3 (2002). For a thorough explanation of how incorrect it is to assume that doctrine is not taught in skills classes, and that skills are not taught in doctrinal classes, see Linda H. Edwards, The Trouble with Categories: What Theory Can Teach Us About the Doctrine-Skills Divide, $64 \mathrm{~J}$. LEGAL EDUC. 181, 190 (2014).

${ }^{15}$ We also agree strongly with critics who note that the skills/doctrine dichotomy has the unfortunate effect of perpetuating inflexible hierarchies within law schools faculties that are based on that dichotomy. In such hierarchies, those who teach so-called "skills" courses tend to be treated as second-class citizens, and are frequently denied tenure and sometimes even voting rights based simply on their status as "skills teachers." See generally Kristen K. Tiscione \& Amy Vorenberg, Podia and Pens: Dismantling the Two-Track System for Legal Research and Writing Faculty, 31 COLUM. J. GENDER \& L. 47, 48 (2015) ("The academy's treatment of LRW faculty, who are singularly focused on preparing students from their first day of law school to think and communicate like lawyers acting on their client's behalf, thus represents a significant equality problem. The current emphasis on skills training makes the status and salary disparity more apparent and more troublesome.").

16 "Realistically, the Carnegie Report realizes that integration in pedagogy cannot be achieved without faculty teamwork, but that kind of communication and mutual respect is discouraged by the in/out structure the 'doctrinal' and 'skills' categories perpetuate. The categories create and maintain divisions among faculty, with the effect that substantive collaborations are less likely. Most faculty members begin their careers and form their professional relationships and allegiances as members of one group or the other. These categorical boundaries discourage border crossings." Edwards, supra note 14 , at 215 . 
(i.e. the knowledge required by lawyers to understand and categorize legal problems presented to them). And it's certainly true that those kinds of knowledge are different in many respects. We do not mean to suggest that there is no difference between "what" knowledge and "how" knowledge. Rather, the authors posit that the problem with our traditional way of thinking and talking about this issue is that it assumes that an individual law course will only be one thing or another.

We observe that the inaccuracy of the skills/doctrine pedagogical dichotomy is brought into sharp focus when a law student engages in a legal writing project for an LRW class. Thus, LRW classes serve as good examples of courses in which skills and doctrine are inextricably meshed. As many scholars have observed, the preparation of legal writing projects-whether by lawyers or students-cannot be understood as anything other than the necessary marriage of skill and doctrine.$^{17} \mathrm{~A}$ student engaging in a legal writing project must be able to understand the doctrine in order to write about it. It is self-evident that a brief, no matter how eloquently drafted, well organized, and cleanly formatted, is of no value to anyone if it misstates the law.

To accommodate this reality, there are many ways in which doctrinal and LRW courses are alike. In Erasing Lines: Integrating the Law School Curriculum, Professor Amy Sloan lists several similarities. ${ }^{18}$ One of the similarities she notes is that "both types of classes involve teaching black letter rules of law." 19 Just as in a doctrinal course, "[i]n a first-year legal research and writing class, memorandum and brief assignments also require students to learn black letter rules of law, understand the policy and theoretical underpinnings of the rules, and apply the rules to different factual scenarios." 20

LRW courses provide a stark example of the insufficiency of the "skills/doctrine" dichotomy to describe the work students do in a particular class. Other courses provide good examples as well. For example, trial advocacy courses

\footnotetext{
17 "Law is the ongoing process of giving written authorities meaning in the context of disputes over what they mean in and for particular situations... The lawyer's persuasiveness depends on his or her understanding of the problem presented, both its factual context and the applicable written authorities. It also depends on the words, argumentative and logical forms and style that the lawyer uses to support the claim. Neither factual and conceptual aspects of the problem, nor compositional skill, is analyzed well when divorced from the other. Both function interactively to make 'law'." Greenshaw, supra note 10 , at 866.

${ }^{18}$ See generally Sloan, supra note 14.

${ }^{19}$ Sloan, supra note 14 , at 5 .

${ }^{20}$ Id. "[S]tudents (and lawyers) do not research and write in the abstract. Legal writers research and write about doctrinal subjects." Christine Hurt, Erasing Lines: Let the Law Professor Without Lines Throw the First Eraser, 1 J. ALWD 80, 83 (2002). Professor Susan DeJarnatt goes further than simply noting that skills and doctrine are taught together in legal writing courses; she goes on to suggest that learning doctrine in a skills-heavy setting has a "synergistic" effect, in which both skills and doctrine are learned better when learned together. "[S]tudents learn doctrine by using it practically and learn practical skills through an increasingly familiar branch of doctrine. Their ability to confront more difficult analytical issues grows as their grasp of the substance increases." Susan L. DeJarnatt, In re MacCrate: Using Consumer Bankruptcy as a Context for Learning in Advanced Legal Writing, 50 J. LeGal Educ. 50, 56 (2000).
} 
that rely upon a simulated client file require a similar investment in student time in learning the black-letter law that applies to the case. It's impossible, after all, to make a compelling closing argument that all the elements of a crime are met if one doesn't understand what the elements are or how they operate in a given jurisdiction. Thus, both LRW and other law professors would be especially well served if we could agree on a better, more accurately descriptive vocabulary for the kinds of knowledge that law school courses teach.

Instead of thinking about a dichotomy of "skills" and "doctrine," the authors instead suggest that we learn to employ the terms "declarative knowledge" and "practical knowledge." This set of terms seeks to describe the difference between static knowledge about a topic area and knowledge about performing a skill-essentially the difference between "what" knowledge and "how" knowledge.

"Declarative" and "practical" knowledge are useful terms because they are less laden with the political and hierarchical baggage of "skills" and "doctrine." Because they do not have entrenched meaning within the legal academy, they can also be more easily used to describe small increments of learning within a course, rather than the course itself. So rather than describing Contracts as a "doctrinal course," as we are accustomed to doing, we could instead say "this is a law course where the declarative knowledge goal is an understanding of contract law doctrine, and the practical knowledge goals are the ability to interpret a contract in accordance with that doctrine, and draft a contractual provision that serves the parties' goals." Such a framing does a better job than "doctrinal course" of teasing out exactly what it is that students are doing in a Contracts class.

However, the terms "declarative knowledge" and "practical knowledge," useful as we hope they may be, mirror the insufficiency of the "skills/doctrine" dichotomy, in that they do not entirely capture the spectrum of knowledge types taught in law courses. This is because the terms do not acknowledge something that, as professors, we ourselves might not wish to acknowledge-that some of what we teach, we teach without deliberately doing so.

Thus, the authors suggest that we also learn to modify these terms, using the words "deliberate" and "incidental." Thus, the knowledge imparted in a law school class could be one of four types: 1) deliberate declarative knowledge; 2) deliberate practical knowledge; 3) incidental practical knowledge; and 4) incidental declarative knowledge. 
Diagram 1

\begin{tabular}{|l|l|l|}
\hline Deliberate & \multicolumn{1}{|c|}{ Declarative } & \multicolumn{1}{c|}{ Practical } \\
\hline Incidental & $\begin{array}{l}\text { Knowledge about } \\
\text { formal doctrine, taught } \\
\text { deliberately as a primary } \\
\text { learning goal }\end{array}$ & $\begin{array}{l}\text { Knowledge about skills } \\
\text { and processes, taught } \\
\text { deliberately as a } \\
\text { primary learning goal }\end{array}$ \\
\hline & $\begin{array}{l}\text { Knowledge about } \\
\text { formal doctrine, taught } \\
\text { incidentally while } \\
\text { pursuing a different } \\
\text { learning goal }\end{array}$ & $\begin{array}{l}\text { Knowledge about skills } \\
\text { and processes, taught } \\
\text { incidentally while } \\
\text { pursuing a different } \\
\text { learning goal }\end{array}$ \\
\hline
\end{tabular}

Deliberate declarative knowledge is the most archetypical type of knowledge taught in the law school setting. When a professor sets out to teach the doctrine of criminal law to a first-year class, she is engaging in a mindful imparting of declarative knowledge to the class. Her learning outcomes will likely be centered on the students' acquisition of criminal law doctrine, most likely from a combination of Supreme Court cases, circuit-level federal cases, state cases, and the Model Penal Code. ${ }^{21}$ She will test for this knowledge in her final exam, and reward the students who can best demonstrate that they have incorporated this doctrine into their own understanding of law.

The second type of knowledge-deliberate practical knowledgeencapsulates the how of lawyering, rather than the what of doctrine. Students learn the processes and procedures of client interviews, court filings, legal research, and document drafting. The MacCrate and Carnegie Reports pushed hard on law schools to increase their offerings of courses in which deliberate practical knowledge is the primary learning goal. ${ }^{22}$ And the ABA requires that accredited law schools establish learning outcomes that include competency in "legal research, ... written and oral communication in the legal context,"

\footnotetext{
${ }^{21}$ Use of the Model Penal Code as a primary teaching tool in $1 \mathrm{~L}$ Criminal Law classes is widespread, but certainly not without its detractors, who note that it is not actually a real statute, that it is no longer cutting edge or revolutionary, and that it has been significantly modified by states that have adopted it. See e.g. Chad Flanders, The One-State Solution to Teaching Criminal Law, or, Leaving the Common Law and the MPC Behind, 8 OHIO ST. J. CRIM. L. 167, 167 (2010) ("[T]here is no uniform code that actually exists as law in all fifty states. While the Model Penal Code (MPC) may serve as a useful stand-in for such a uniform law, few, if any, states have adopted the MPC in its entirety, and most have rung interesting changes on it, accepting some parts and rejecting or modifying others."). ${ }^{22}$ Of course, traditional "skills" courses are not the only places in which deliberate practical knowledge is imparted. The best example of a course that blends deliberate practical knowledge and deliberate declarative knowledge may be a Civil Procedure course, in which the instructor requires that students use both a casebook that covers the doctrine of jurisdiction and the Federal Rules of Civil Procedure. Civil Procedure, when taught using this method, is intended to teach students the doctrinal underpinning of the rules (the what) and help students gain a rudimentary understanding of the process of civil case filing (the how).

${ }^{23}$ Section of Legal Educ. AND Admissions to the Bar, Am. BAR Ass'n, ABA Standards AND
} 
professional skills needed for competent and ethical participation as a member of the legal profession." 24

Deliberate practical knowledge is mainly taught in classes traditionally considered "skills" courses, such as negotiating and counseling classes, first-year LRW classes, clinics, and trial advocacy classes. But even most traditional "doctrinal" classes contain an element of deliberate practical knowledge. However, in those courses, the quantity of that knowledge may vary with the instructor's approach. Let us imagine the first-year Criminal Law classroom. Most criminal law professors will mindfully construct an exam that tests for declarative knowledge, but usually that exam will take the form of a series of fact patterns that require long-form essay answers. This standard testing method is generally recognized to test not only for the declarative knowledge deliberately taught, but also for the ability to select for relevant facts, and to determine which category of doctrinal knowledge must be analyzed in order to determine and communicate the correct answer. This skill, which we commonly refer to as "issue-spotting," is a kind of "how" knowledge-how to sift through a set of facts and connect the facts to the doctrine. Students taking an average law school exam will also be tested on their ability to manage time well, to commit information to memory (if the exam is a closed-book format), to research quickly and accurately (if the exam is an open-book format), to remain calm under pressure, and to write clear, well organized responses to queries. Thus, in most criminal law classes, the teaching of at least some of this kind of practical knowledge is deliberate. ${ }^{25}$

Law classes often also involve the incidental teaching of practical knowledge. Incidental practical knowledge is produced across the law school curriculum, although not mindfully contemplated by instructors as being part of the desired learning outcomes of the course. For example, let us imagine a seminar on patent law. In it, an instructor pauses a PowerPoint on non-obviousness to tell a war story about the requirement's effect on the actual practice of patent law. The war story is intended to demonstrate the limitations of the non-obviousness requirement's clarity and effectiveness-the instructor means for the story to impart declarative knowledge. However, the story also serves another purpose that, while beneficial to the students' learning, was not intended. It demonstrates something

Rules of Procedure FOR APPROVAL OF LAW SCHOOLs 2017-2018, STANDARD 302(b), at 15 (2017).

${ }^{24} I d$. at 15, STANDARD 302(d). Interpretation 302-1 states that other professional skills may include "interviewing, counseling, negotiation, fact development and analysis, trial practice, document drafting, conflict resolution, organization and management of legal work, collaboration, cultural competency, and self-evaluation." $I d$. at 16.

${ }^{25}$ In the wake of the MacCrate and Carnegie reports and their emphases on skills development, many professors of classes such as Criminal Law have made the determination to incorporate even more deliberate practical knowledge into their courses. See e.g., Cynthia Alkon, Making a Deal in Criminal Law, 10 OHIO ST. J. OF CRIM. L. 643, 643-45 (2013) (describing criminal law course that incorporates plea bargaining exercises that allow students to use negotiation skills to comprehend the doctrinal material while also infusing ethics and strategy into the construct); Steven I. Friedland, Role Reversal: Letting Students Ask the Questions in a Criminal Law Class, 10 OHIO ST. J. OF CRIM. L. $651,651-55$ (2013) (discussing criminal law course in which the professor conducts an exercise to enhance students' questioning skills). 
about the way in which patent lawyers go about their work, and illuminates part of the patent filing process that the instructor does not necessarily expect all of the students in the class to grasp or retain. Some students may not catch this knowledge as it floats by, but others-perhaps those most interested in the practice of patent law-will file it away, perhaps to be used the first time the student attempts to file a patent him or herself.

The fourth category of knowledge is incidental declarative knowledge. This type of knowledge is most often imparted in the process of teaching one of the classes traditionally seen as a "skills" class. For example, imagine that a student has enrolled in Introduction to Trial Advocacy. The course's stated purpose is to teach students the skills required to effectively represent clients in a trial setting. Those skills include the preparation of opening and closing statements, direct and cross examinations, the ability to determine which case theory would be most effective, the ability to authenticate documents for admission purposes, the ability to object and answer objections effectively, and a whole host of other "how" items. All of this would fall into the category of "deliberate practical knowledge."

Of course, in order to properly authenticate a document or object to a question, a student would have to know the rules of evidence. This might be taught prior to the Trial Advocacy class, or might be taught in an integrated fashion, concurrently with the trial skills. If the latter is true, this Trial Advocacy class would also contain some elements of deliberate declarative knowledge.

But there is more to this class than meets the eye. In order to prepare for trial, there must be a trial, and the trial must be about a cause of action. Let us say that this Trial Advocacy class uses a simulated fact pattern (as many such courses do). And let us say that the fact pattern is about an imaginary jurisdiction's Dram Shop Act. In order to make an effective opening statement, the student will have to read and understand the imaginary statute that lies at the heart of the dispute. It is unlikely that the course planners determined that a goal of the course would be to understand the State of Confusion's Dram Shop Act-and yet, the student must do exactly that. The cause of action does not have to be about the State of Confusion's Dram Shop Act. It could just as easily be about the Antidiscrimination Act of State XYZ, or about a dispute over the deed to Blackacre. The declarative knowledge learned in the class is both incidentally transmitted and fungible-its sole purpose is to assist in the transmission of practical knowledge. This kind of knowledge, which is declarative in nature but unlinked to any contemplated course goals, is what the authors call "incidental declarative knowledge."

\section{INCIDENTAL DECLARATIVE KNOWLEDGE IN LRW SIMULATION DESIGN-THE PROBLEM WITH THE PROBLEM}

In this section, we explore how declarative knowledge is produced in law school simulation courses, using the LRW classroom as an entry point to this discussion. The authors will demonstrate that, despite a plethora of scholarship on the issue of LRW problem design, very little attention has been paid to the question of what type of declarative knowledge is being produced in the LRW classroom. 
The authors posit that declarative knowledge in the LRW setting is still very frequently incidental in nature. The authors further suggest that this state of affairs is not an ideal learning environment for law students.

Section A of this Part briefly discusses the evolution of LRW course design from instruction that focused almost exclusively on the writing product (deliberate practical knowledge) to today's LRW courses that guide students through the complex recursive process of legal writing and analysis. As the goals of LRW courses have shifted towards a greater emphasis on legal analysis, the substantive law upon which assignments are based (the declarative knowledge) has become a more important pedagogical consideration.

Section B provides an overview of different approaches to LRW course design, specifically considerations influencing the selection of the substantive law underpinning a legal writing assignment. Finally, Section $\mathrm{C}$ discusses other approaches to LRW course and problem design that have emphasized declarative knowledge production along with skills development.

\section{A. Design of First-Year LRW Courses}

In the last twenty-five years, legal research and writing pedagogy has undergone a significant shift from a focus on "the product of writing to the process of writing. ${ }^{.26}$ In the early day $\mathrm{s}^{27}$, writing was thought of as separate from analysis, and the focus was on practical knowledge development: teaching students how to produce legal memoranda, briefs, etc. ${ }^{28}$ Under this product-focused approach to LRW, the professor would typically provide the students with an example of a particular legal document, such as a legal memorandum, "and review the final product for error-free prose and clarity. The professor did not engage with the students in the process of analysis, assuming that the thinking process was completed before the writing process began." 29

As LRW pedagogy continued to evolve, professors began to lead students through the process of writing rather than solely focusing on the end product. ${ }^{30}$ LRW professors taught the "component parts of legal analysis in incremental steps, incorporating writing assignments designed to reinforce those steps, in a

\footnotetext{
${ }^{26}$ Ellie Margolis \& Susan L. DeJarnatt, Moving Beyond Product to Process: Building a Better LRW Program, 46 Santa ClaRa L. Rev. 93, 98 (2005)

${ }^{27}$ Legal writing as a discipline has only been around since the 1950 s. Id. at 94 .

${ }^{28}$ Gail Anne Kintzer et al., Rule-Based Legal Writing Problems: A Pedagogical Approach, 3 LEGAL WritING: J. LEGAL WrITING InST. 143, 144 (1997); see also Margolis \& DeJarnatt, supra note 26, at 94-95; Laurie A. Kadoch, The Third Paradigm: Bringing Legal Writing "Out of the Box" and Into the Mainstream: A Marriage of Doctrinal Subject Matter and Legal Writing Doctrine, 13 LEGAL WRITING: J. LEGAL WRITING INST. 55, 62-64 (2007) (discussing the origins of the product-based approach to legal writing pedagogy).

${ }^{29}$ Margolis \& DeJarnatt, supra note 26 , at 98.

${ }^{30}$ See Kadoch, supra note 28 , at 63 (discussing the evolution of teaching writing as a recursive process).
} 
progression from simple to complex." ${ }^{\text {"31 }}$ Students were typically given a series of assignments designed to help them build the analytical and writing skills that would prepare them to write a complete legal memorandum by the end of the first semester of LRW. ${ }^{32}$ For example, students might be assigned "a memorandum's factual summary or issue statement as [a] separate, short, initial [project]. ${ }^{33}$ Often, however, interim assignments were not related to the students' final work product. ${ }^{34}$

Furthermore, research skills were often taught in a separate course.$^{35}$ And even when research was included in the LRW course, research was "taught through independent exercises unrelated to a writing assignment." ${ }^{\text {" Th }}$ These "treasure hunt" or "Easter egg" library assignments were exclusively focused on practical knowledge development and had the effect of disassociating research and writing in LRW programs. ${ }^{37}$

Today, rather than teaching just writing or just research, the LRW course teaches a much more integrated skill set-learning how to "think, write and speak like a lawyer." 38 Students learn the process of "critically analyzing legal problems" -defining the issue, identifying relevant facts, developing a research plan, finding relevant legal resources, refining the issue through one's research, further refining the research task, analyzing the law and facts to answer the client's questions, returning to research the gaps in analysis that the writing process reveals, and finally communicating that analysis in writing and in speech. ${ }^{39}$ Essentially, students learn how to teach themselves a new area of law (declarative knowledge development), and then to communicate what they have learned effectively. ${ }^{40}$

"Thus, students in LRW learn substantive law in part by learning about legal research." ${ }^{41}$ However, this "is not a simple linear process of finding the cases,

\footnotetext{
${ }^{31}$ Kintzer et. al., supra note 28 , at 145 . This "structured progression" is consistent with cognitivism learning theory. See Thrower, supra note 9 , at 19.

${ }_{32}^{32}$ Margolis \& DeJarnatt, supra note 26, at 107.

${ }^{33}$ Greenshaw, supra note 10, at 893.

${ }^{34}$ Margolis \& DeJarnatt, supra note 26, at 117-18.

${ }^{35} \mathrm{Id}$. at 107 .

${ }^{36} \mathrm{Id}$.

${ }^{37}$ See id. at 111-13. Another type of assignment common in past iterations of LRW courses was the so-called "closed universe" memorandum. The idea of a closed universe problem is to simplify the assignment by eliminating the research task, thus allowing the students to concentrate on legal analysis. However, although students effectively learn basic legal analysis, closed universe memos "do not prepare students for the complexity of analysis required when approaching a client problem from the beginning, with no handy packet of materials provided." $I d$. at 113.

${ }^{38} \mathrm{Id}$. at 95 .

${ }^{39} I d$. at $99,113-14$.

${ }^{40}$ This is also a challenging way to learn doctrine, but it is an important skill for students to develop because every practitioner must know how to teach him/herself a substantive area of law. "Learning a substantive area through writing about it requires an enormous effort at the beginning to understand enough about the most basic aspects of the issues to accomplish the assigned task. But this is true for any writing project in an unfamiliar area." DeJarnatt, supra note 20 , at 68.

${ }^{41}$ Sloan, supra note 14 , at 6.
} 
organizing them, outlining, and writing up the results."42 It is through the complex recursive process ${ }^{43}$ of analyzing and writing that students construct meaning, ${ }^{44}$ and become prepared to "enter the discourse community of lawyers and to practice law." $" 45$

At Temple, as at many other schools with well-developed LRW programs, we guide students in the recursive process by "teaching-through-the-problem," which means "us[ing] . . . the assignments as the vehicle for all teaching." ${ }^{\text {" Rather }}$ than providing students with a "closed universe" of legal resources, "all assignments include open-ended research leading to a full memorandum," other legal work product, such as a client letter, email memorandum, or motion brief. ${ }^{48}$ Teaching-through-the-problem involves "the full integration of research and writing. Students begin learning the discourse of law by practicing the full discourse, not by learning it in discrete, unconnected steps. "49 Courses based on the "full integration" of practical and declarative knowledge development allow students to "more easily . . . experience the interpretive framework they need to make sense of legal analysis."

But how do LRW professors design assignments that will meet this variety of pedagogical goals? Is declarative knowledge development one of the foremost considerations in problem design? If not, what other considerations affect the professor's decision to base an assignment on contracts versus torts or property versus criminal law? In the next section, the authors discuss problem design

\footnotetext{
${ }^{42}$ Margolis \& DeJarnatt, supra note 26, at 114.

${ }^{43}$ This recursive process of learning is consistent with constructivist learning theory. Constructivists believe that students do not "assimilate instruction intact," but instead they "create new knowledge, interpreting instruction in the context of their own experiences and their social relationships." Thrower, supra note 9, at 19. Constructivist learning theory has four characteristics: 1) "that a student's new learning depends on an earlier knowledge base"; 2) "that students create-or construct - their own understanding, rather than passively receiving new information in already constructed forms"; 3) "that social interaction among students creates an environment in which students can test and modify their ideas in light of their classmates' viewpoints"; and 4) "the use of authentic tasks to promote learning." Id. at 19-21. Application of constructivist learning theory is evident in the ways that LRW professors traditionally teach, including in the LRW program at Temple University Beasley School of Law. Id. at 21.

${ }^{44}$ Margolis \& DeJarnatt, supra note 26, at 98-99, 113-14.

${ }^{45} \mathrm{Id}$. at 108 . A "discourse community" is "a restricted community made up only of people who know the particular forms ... A law student needs to learn how to write in the discipline of lawyers, as opposed to learning how to write in some other discipline-some other profession." Thrower, supra note 9 , at 22.

${ }_{46}$ Margolis \& DeJarnatt, supra note 26, at 108, 117. This approach is consistent with the first two characteristics of constructivist learning theory, see note 45 , in "which the professor visits and revisits material over the course of the year, packaging and repackaging it in different forms while employing different tools." Thrower, supra note 9 , at 20 .

${ }^{47}$ Margolis \& DeJarnatt, supra note 26, at 107

${ }^{48}$ This is consistent with the fourth characteristic of constructivist theory: that students respond best to real world assignments that are grounded in reality. See Thrower, supra note 9, at 21. "[R]ealworld problems better prepare students to work as lawyers." Id. at 28.

${ }^{49}$ Margolis \& DeJarnatt, supra note 26, at 109.

${ }^{50} I d$. at $109-10$
} 
considerations, specifically why professors choose the particular substantive law upon which their assignments are based.

\section{B. Considerations Affecting Declarative Knowledge Development: Approaches to Selecting the Substantive Basis for an LRW Problem}

Many considerations go into designing an effective LRW assignment. A "problem must be challenging, involve issues that are both realistic and arguable, be culturally sensitive, [must] stretch the students' analytical and research skills without overwhelming them," and if the assignment involves persuasive writing, the problem must be "balanced." Traditionally, the problem creation process centered on the development of practical knowledge, and not on the development of declarative knowledge. As a consequence, instructors were advised to begin with an inventory of skills that the students should master before giving any consideration to the substantive law upon which the assignment would be based. ${ }^{52}$ The black letter law was viewed as a fungible aspect of the class that varied based on skills-based pedagogical goals. ${ }^{53}$

Once LRW instructors turned to the question of choice of substantive law, they have traditionally been advised to choose the substantive legal area based

${ }^{51} I d$. at 131 .

${ }^{52}$ See e.g., Grace Tonner \& Diana Pratt, Selecting and Designing Effective Legal Writing Problems, 3 LEGAL WRITING: J. LEGAL WRITING INST. 163 (1997). "Legal writing problems are effective only in the context of the overall course design. Begin with the skills you want the students to achieve in research, analy sis, organization, predictive writing, and persuasion. In research, students should learn to use the basic research tools effectively and efficiently, and they should learn to develop effective strategies for choosing the most fruitful approaches to researching individual problems and issues. Consider, too, the timing and sequence of book and electronic research. The analytical goals are numerous. Students must learn to identify issues and break the problem into its smallest analytical components. They need to become adept at defining general principles precisely and accurately, and they need to be able to present cases to set up the analogies and distinctions they will draw in analyzing a legal problem. They will learn inductive reasoning to define general principles from one and later a group of cases. They will learn deductive reasoning and the use of syllogisms to prove their analysis to the reader. The organizational goals include developing judgment about what is most important, learning IRAC and its variations, and learning to arrange issues and arguments. Finally, our students should learn to write precisely and directly in both a predictive and a persuasive mode tuned to the particular audience. The sequence of problems should allow the students to learn the basic skills and master them as they reappear in later and more complicated problems." Id. at 163164.

${ }^{53}$ See Sloan, supra note 14, at 5-6. "In a first-year legal research and writing class, memorandum and brief assignments also require students to learn black letter rules of law, understand the policy and theoretical underpinnings of the rules, and apply the rules to different factual scenarios. Most legal research and writing classes are not tied to specific substantive areas of law. As a consequence, they differ from doctrinal classes in that the subject area of the black letter rules that students learn can vary from year to year or even from section to section." Id. at 5-6. Additionally, over the span of a single LRW course, assignments may have been based on multiple areas of law. See Thrower, supra note 9 , at 4-5. "Without a designated subject matter, most legal writing courses involve assignments from many different subject areas. Students may start out the school year working on a torts problem; their second assignment might be a criminal matter; and their final assignment might involve 
upon a wide range of considerations. The primary consideration that has often been suggested has been the complexity of the law-specifically, whether first-year students would be able to grasp the relevant legal concepts. ${ }^{54}$ If the substantive law was too complex, it would detract from learning the targeted skills. Therefore, experts advised instructors to either choose a straightforward common law cause of action with a clear set of elements or a cause of action based on a statute with a simple construction. ${ }^{55}$

Experts on problem design have suggested additional considerations, such as whether the problem will be based on federal law or state law (the decision being based on what type of authority the professor wants the students to learn how to analyze). ${ }^{56}$ Yet another consideration in the choice of substantive law is the professor's own ability to gain mastery of the problem. Some professors have chosen to base their LRW assignments on their own practice experience, ${ }^{57}$ enjoyment of the substantive issue, ${ }^{58}$ or knowledge of the substantive area based on scholarship. ${ }^{59}$

Although these considerations are logical approaches to problem design, they all ignore the core question of what the students are learning. Thus, the declarative knowledge produced in most first-year LRW classes is likely to be

constitutional law." Id. at 4. See also Kintzer et al., supra note 28 , at 144.

54 See Lucia Ann Silecchia, Legal Skills Training in the First Year of Law School: Research? Writing? Analysis? Or More?, 100 DICK. L. REV. 245, 277 (1996) (advising that "it may be unwise to include certain topics in the first year curriculum" because they may be too difficult for students to handle early in their legal education); Lorraine Bannai et al.,_Sailing Through Designing Memo Assignments, 5 LEGAL WRITING: J. LEGAL WRITING INST. 193, 199 (1999) (asserting that the "most common mistake in designing legal writing assignments is creating an assignment that is too difficult"). To manage the complexity of the assignment, professors were advised "to draft assignments that involve areas of law ... with which students are familiar or can easily become familiar. $I d$. at 204 .

${ }^{55} I d$. at 193. "[E]arly assignments should involve a rule with a fairly clear organizational approach." $I d$. at 202. Moreover, if students were assigned a "closed universe" problem, then the professor could further control the complexity of the substantive legal analysis by preselecting the authorities that the students would apply. See also Margolis \& DeJarnatt, supra note 26, defining the "closed universe" type of assignment.

${ }^{56}$ See e.g., Bannai et al., supra note 54 . When considering analysis goals, professors should decide whether the problem will involve "common law or statutory analysis, an issue of first impression or a split of authority." Id. at 208-09.

${ }^{57}$ See e.g., $i d$. at 210 (suggesting that the professor's practice experience and the practice experience of friends could be a source for designing an LRW problem); Thrower, supra note 9, at 44-45 (discussing how professors benefit from bringing their practical experience to the LRW classroom).

${ }^{58}$ See e.g., Tonner \& Pratt, supra note 52, at 170, 173 (suggesting that an LRW professor choose an area of law that he or she enjoys because their enthusiasm will be communicated to the students and the professor will be in a better position to help the students "focus on the relevant authority"); Susan P. Liemer, Many Birds, One Stone: Teaching the Law You Love, in Legal Writing Class, 53 J. LEGAL EDUC. 284, 288-293 (2003) (discussing the benefits of teaching an LRW assignment based on a substantive area that the professor enjoys); Thrower, supra note 9 , at 44 (stating when "teachers . . can teach what they know and like; this, then, makes specialized instruction pedagogically sound from the teacher's perspective.").

${ }^{59}$ See e.g., DeJarnatt, supra note 20, at 57 (author chose bankruptcy law as the substantive basis for her advanced LRW course based on her experience as a practitioner and scholar). 
incidental in nature. ${ }^{60}$ All of these approaches to problem design make some sense. After all, it is rational to consider first-year law students' relative inexperience in interpreting statutes, so perhaps ERISA is not the best choice. It is rational to want one's professor to be engaged with the material, or else the class environment risks becoming a zone of deathly boredom. And of course, no one should teach law they do not understand.

The problem with all of these approaches is that they miss one critically important question-whether the substantive law itself is of value to the students. Not the form it comes in or the jurisdiction from which it originates, but the actual rules contained in the law. Using this approach, any law that is interesting to the professor, understandable to the student, and fulfills the other considerations listed above would work just fine. The substantive law, in other words, is fungible, and not taught for its own value. There is no expectation that any student in the class, much less many or all students in the class, will ever really need to know the substantive rules that they are tasked with learning. Thus, the knowledge that is produced when a student learns using this method falls into the category of incidental declarative knowledge.

However, some have advocated for a more deliberate approach to choosing the substantive law upon which LRW assignments are based. In the next section, the authors discuss a few programs that emphasize declarative knowledge development in LRW curricular design.

\section{Models for Teaching Declarative Knowledge Deliberately in the LRW Classroom}

Other scholars have, in fact, advised making the substantive law the foremost consideration when designing an LRW assignment. For example, Professor Sue Liemer advised that a "purposeful connection to an area of substantive law" with skills training allows students to learn "the connection between doctrine learned in law school and its use in law practice. ${ }^{.61}$ Other

\footnotetext{
${ }^{60}$ We note that advanced legal writing classes may be more likely to be organized around a specific issue area, and thus, the declarative knowledge they produce may tend to be more deliberate than incidental. Michael R. Smith, for example, mentioned using an advanced legal writing course as "an opportunity to integrate writing instruction with a specific doctrinal area." Michael $\mathrm{R}$. Smith, Alternative Substantive Approaches to Advanced Legal Writing Courses, 54 J. Legal Educ. 119,120 (2004). Susan Thrower also discusses specialized advanced legal writing classes in her article. Thrower, supra note 9, at 12.) And Susan DeJarnatt's MacCrate article also discusses an advanced writing course based on bankruptcy law. DeJarnatt, supra note 20.

${ }^{61}$ Liemer, supra note 58, at 286 . When deciding on the substantive law that will form the basis of a LRW assignment, Professor Liemer suggests that professors consider the "learning opportunities for law students beyond fundamental lawyering skills." Id. at 285 . For example, "[s]ome LRW teachers base a problem on an underlying procedural matter or set it in a particular procedural posture, to strengthen the students' understanding of both civil procedure and lawyering skills. Just as with the purposeful connection to an area of substantive law, connecting instruction in procedure with instruction in LRW skills shows students how the two are linked in law practice." Id. at 286.
} 
scholars suggest basing LRW problems on one of the "students' first-year subjects. Using first-year subjects will help the students see how their courses work in application, thereby reinforcing learning in both the doctrinal course involved and the Legal Writing course." ${ }^{22}$ One LRW professor chose to base a legal writing assignment on substantive law that was consistent with the mission of the law school. $^{63}$

And in fact, a few law schools have put this principle into practice by building their entire 1L LRW program around the principle that declarative knowledge ought to be taught deliberately. One such example (now defunct) existed at the University of Iowa College of Law. Iowa had one of the relatively few faculties that taught legal writing as substantive course work in the first-year curriculum. ${ }^{64}$ The "Iowa approach," "fully integrated legal writing and doctrine by using casebook faculty to teach legal writing through their courses." ${ }^{965}$ Professor David Vernon and Dean William Hines justified the Iowa program in terms of thorough education in the law. "They asserted that the real problem [was] not students' lack of writing skills, such as the ability to put words, sentences, and paragraphs together; rather, the problem [was] students' failure to 'understand what it is that they are writing about.' It was their experience that students improved their writing as they gained an understanding of what it was that they were writing. ${ }^{.66}$

The University of Maryland School of Law applies the "teach a first-year subject" idea a bit differently than the Iowa approach. According to Professor

${ }^{62}$ Bannai et al., supra note 54, at 205-06; see also Tonner \& Pratt, supra note 52, at 168 ("In designing expository problems[,] . . it is best to use first year topics. They are more accessible to the students, and your problems can enhance the learning that is occurring in other courses.")

63 "[A]t Howard University [the LRW director] routinely gave his LRW students an assignment with a Title VII component. Learning about employment discrimination fit well with his law school's mission, and he wanted to be sure all his LRW students knew something about discrimination law." Liemer, supra note 58 , at 285 n. 7.

${ }_{65}^{64}$ Greenshaw, supra note 10 , at 865 .

${ }^{65}$ Thrower, supra note 9, at 16. The University of Iowa College of Law no longer follows this approach. The faculty voted to create a separate LRW course in 2007. Id. at $16 \mathrm{n}$. 44. Interestingly, the Iowa program did not create a legacy of imitator programs. Professor Thrower surmised that "the fact that a majority of schools have turned away from the Iowa model, some in order to satisfy the demands of the MacCrate Report, suggests that the Iowa model is not effective at communicating the essential core skills and concepts underlying legal writing doctrine." Id. at 17.

${ }^{66}$ Greenshaw, supra note 10 , at 865 . "[O]ne cannot entirely divorce writing from the knowledge it expresses, and therefore some doctrine and analysis must necessarily be taught with legal writing. However, [Vernon's and Hines'] view implies more than the logical and practical inevitability of teaching with some substance along with writing skills. It is consistent with understanding law as a process in which content and skill in composition interact, and in which legal writing is more than the expression of legal ideas in words." Id. at. 866. "[S]tudents have to understand the problem presented before they can improve their writing ... [This] suggests that the understanding of legal subject matter and effective composition are related, so closely related that the latter is not taught effectively without the former." Id. at 873 (quoting David H. Vernon \& N. William Hines, Guidelines for Preserving the English Language, 4 LEARNING AND THE LAW 26, 26 (1977)). "[C]ontent and composition are integrally related. Therefore, when students learn legal writing they are learning the 'law'." Id. 
Susan Hankin, "Maryland's program is an example of an integrated curriculum that marries lawyering skills, legal analysis, and, to a lesser but growing degree, professionalism from day one of the students' law school career ... [T] he program supports inter-curricular faculty work by having traditional 'doctrinal' faculty teach [Legal Analysis and Writing] LA\&W while at the same time traditional 'legal writing' faculty teach a doctrinal course, with members of both groups working together in regularly scheduled teaching meetings and in less formal settings." ${ }^{, 67}$ Clearly, this method can only be installed in a law school with the will to perform a significant overhaul of the traditional first year and the commitment to a great deal of collaboration among the faculty.

DePaul takes a different approach, offering special sections of LRW (called LARC at that institution) with specific subject matter. "At DePaul University College of Law . . some legal writing sections are purposely specialized: they are populated with students who have identified an interest in a particular area of law." ${ }^{\circ 8}$ DePaul offers specialized legal writing sections in child and family law, intellectual property law, and public interest law. ${ }^{69}$ Students must apply to be enrolled in one of these specialized legal writing sections. ${ }^{70}$ "Thus, students learn the skills of writing and analysis while working through the nuances of a legal specialty to which they anticipate a long-term commitment." ${ }^{\text {"7l }}$ However, there are structural limitations on the sections' ability to focus the entirety of the course on that single concentration. ${ }^{72}$

Each of the models discussed above do something important. They transform incidental declarative knowledge into deliberate declarative knowledge.

${ }^{67}$ Susan J. Hankin, Bridging Gaps and Blurring Lines: Integrating Analysis, Writing, Doctrine, and Theory, 17 LEgAL Writing: J. LeGAL Writing InST. 325, 341 (2011).

${ }^{68}$ Thrower, supra note 9, at 4. DePaul's first year legal writing course is called Legal Analysis, Research \& Communication (LARC). DePaul students take LARC I and II in their first year and are required to take LARC III in their second year. Id. at 5; DePAUl College of LAW, Legal Writing, https://law.depaul.edu/academics/experiential-learning/legal-writing/Pages/default.aspx.

69 DePAUl COllege OF LAW, LEGAL Writing, https://law.depaul.edu/academics/experientiallearning/legal-writing/Pages/specialized-coursework.aspx. "First-year, full-time students may apply for one of three special sections focusing on child and family law, intellectual property law (including IP Law, IP: Information Technology Law and IP: Arts and Museum Law) and public interest law."

70 Thrower, supra note 9, at 9-10; DePaul College OF Law, Legal Writing, https://law depaul.edu/academics/experiential-learning/legal-writing/Pages/specialized-

coursework.aspx.

${ }^{71}$ Thrower, supra note 9 , at 4 .

${ }^{72}$ However, these specialized legal writing sections do not purport to teach substantive law in the same manner as the subject would be taught in more traditional doctrinal course. Instead, the focus is on "learning the skills and doctrine of legal writing: synthesis of multiple authorities, legal analy sis, research, and legal citation." $I d$. at 11. Professor Thrower describes the substantive law that students in these specialized sections learn as "an adjunct to their research and writing." Id. at 11. To that end, each faculty member in the LARC program is required to meet additional, practical learning goals, and include federal law and state law, civil law and criminal law, statutes and common law. Id. at 11 . To meet these programmatic requirements, some assignments may not be based on the specialized substantive area of law. Id. at 11-12. "To illustrate, the field of intellectual property is entirely statutory. Under departmental requirements, however, the [Intellectual Property/Legal Writing] professors must create an assignment using common law and, thus, cannot use intellectual property as the legal basis for at least one assignment." $I d$. at 12. 
And in so doing, they avoid the problem of students spending their time and energy learning an area of law that may well prove functionally useless to them once their utility as a vehicle for practical knowledge production has been exhausted. The LRW-based approaches considered above might also work outside of the LRW context, in other simulation-based, practice-focused courses. In Part IV, the authors offer another, highly effective approach to considering declarative knowledge development in LRW problem design.

\section{PROFESSIONAL RESPONSIBILITY AS A SOLUTION}

Part IV describes the authors' experience in using professional responsibility as a solution to the incidental declarative knowledge problem in LRW course design. This Part delves into the authors' reasons for choosing professional responsibility and the advantages and disadvantages of this choice, as well as the specific design of the LRW problem that the authors developed.

\section{A. Why Professional Responsibility?}

The authors wanted to create a problem in which declarative knowledge was taught deliberately, and not incidentally. The challenge, however, was to locate an area of substantive law that would prove useful to our students. $1 \mathrm{~L}$ classes are full of disparate students with different goals, and our LRW classes are not subject-specific. Eventually we realized that, with few exceptions, our students have at least one thing in common-they are hoping to become practicing attorneys. And as such, they will all be bound by the expectations of the legal profession.

Despite knowing that they want to be lawyers, 1Ls are only beginning to figure out the question of what it means to be a lawyer. Many have had little or no experience with law or lawyers, having no family members or friends who are attorneys or judges. This is particularly true of less-privileged students, who may already be coming to law school with a deficit of confidence. As other scholars have noted, law students can benefit from exposure to professional norms as quickly as possible, so that they can view the remainder of their law school careers 
through a lens of ethical practice. ${ }^{73}$ We chose, therefore, to use a legal malpractice claim as the basis for our LRW problem. ${ }^{74}$

By using a legal malpractice problem, we introduce our students to issues of professional norms by the second half of their first semester in law school. Because legal malpractice claims contain three elements-duty, breach, and proximate causation-we can expose students to several critical professionalism issues in the context of a tort, which they can understand fairly well, given that Torts is a Fall $1 \mathrm{~L}$ class at Temple. ${ }^{75}$

The question of "duty" helps students understand something very important-that to certain people, they will become more than just an average person. They learn the centrality of the question of who is a client and who is not a client, and hopefully will internalize the message that clarifying the existence or absence of an attorney-client relationship is vital to their wellbeing as practitioners. And they also learn that if a person is a non-client, they may under certain circumstances still owe that person a duty.

The element of breach introduces students to the fundamental question of what is expected of them as lawyers. They learn that they are expected to be

\footnotetext{
${ }^{73}$ The few scholars who have suggested teaching professional responsibility in LRW have pointed to the development of professional identity and general awareness of legal ethics as considerations. Professor Liemer, for example, suggested "professionalism and lawyering ethics" as a suitable first year LRW assignment topic because students learn to associate "an awareness of ethics" with the use of their legal skills. Liemer, supra note 61 , at 287 . Furthermore, early education in professional responsibility will "increase the likelihood that the bar of the future will meet its ethical obligations and serve all parts of society well." $I d$. Lorraine Bannai suggested that professors consider "drafting assignments involving the regulation of the legal profession, for example, attorney admissions and disbarment proceedings. Students can readily relate to these issues as they know they will soon be subject to these rules." Bannai et al., supra note 54, at 206. Lucia Ann Silecchia also recommended using a legal malpractice problem in a first year LRW course, but from a different perspective. She views a legal malpractice issue as an opportunity to teach students a variety of legal skills, such as "law office management," "professional responsibility," and conducting adequate legal research. Silecchia, supra note 54, at 289.

${ }^{74}$ Teaching professional responsibility is also valuable to students because they will one day almost certainly have to take the MPRE. According to the National Conference of Bar Examiners, which writes and administers the MPRE, "[t]he Multistate Professional Responsibility Examination (MPRE) is a two-hour, 60-question multiple-choice examination developed by NCBE that is administered three times per year. It is required for admission to the bars of all but three U.S. jurisdictions." NAT'L. CONF. BAR Examiners, Multistate Professional Responsibility EXAMINATION, http://www.ncbex.org/exams/mpre/. "The purpose of the MPRE is to measure examinees' knowledge and understanding of established standards related to the professional conduct of lawyers.... The law governing the conduct of lawyers in these roles is applied in disciplinary and bar admission procedures, and by courts in dealing with issues of appearance, representation, privilege, disqualification, and contempt or other censure, and in lawsuits seeking to establish liability for malpractice and other civil or criminal wrongs committed by a lawyer while acting in a professional capacity." Id. The MPRE specifically tests on attorney competence, civil liability to clients and non-clients, and the formation of the attorney-client relationship. See NAT'L CONF. BAR. EXAMINERS, MPRE SUBJECT MATTER OUTLINE, http://www.ncbex.org/pdfviewer/?file=\%2Fdmsdocument $\% 2 \mathrm{~F} 2$.

${ }^{75}$ Research into legal malpractice claims also often overlaps with bodies of attorney disciplinary case law, which provides students with a second perspective on the consequences of poor lawyering
} 
reasonably diligent, to research things they do not yet know, to communicate well with clients, and to not mislead. Proximate causation-probably the slipperiest of the three elements-demonstrates to students that their actions as lawyers may have real and damaging consequences to their clients, and that they will be held responsible for those consequences.

Teaching attorney malpractice in the first year LRW class also helps to address a long-standing tension in legal academia ${ }^{76}$ about when and how to teach professional responsibility. Legal educators understand that learning is enhanced in an experiential setting, so if we have to teach professional responsibility, a simulation course is a good place to do it. ${ }^{77}$ Professional responsibility is particularly suited to experiential learning adaptations.

Professional responsibility should be taught by the broadest possible experiential education model; it should expose students to as many lawyerly roles as possible, including the traditional classroom legal education role of lawyer as law reader and analyzer. The law of professional responsibility is the same as the law of other fields in that it is about law[.] [However,] it is different from all other law fields in another crucial way: although the lawyer vicariously interacts with the law of contracts and torts through clients' experiences, the lawyer directly experiences professional responsibility law as the central actor in all of the relationships that professional responsibility law is about. This difference suggests that experiential methods may be more effective in the teaching of professional responsibility law than in other areas of law. $^{78}$

\footnotetext{
${ }^{76}$ See generally Kathleen J. Woody, Professional Responsibility Training in Law School and its Philosophical Background, 7 J. LEGAL Prof. 119 (1981) (discussing the teaching methods, content, class structure and timing of the professional responsibility course). For many years, the "prevailing view was that professional responsibility could not be taught. If law students did not know the difference between right and wrong by the time they reached law school, nothing law professors could do would make a difference." Id. at 121 . "By the early 1970 s, states had begun to require professional responsibility training by law schools as a prerequisite to bar membership ... [and] the $\mathrm{ABA}$ and the state legislatures [began] to make increasingly specific requirements for ... professional responsibility training." Id. at 122-23.

77 " [S]cholars have documented the benefits of teaching ethics in clinical contexts, but role-playing exercises can achieve similar ends; simulations allow students to step into the shoes of lawyers and other actors in real practice dilemmas and policy controversies and to enter the subjective experiences of the people involved. They help students appreciate external influences on lawyer conduct and the consequences of lawyers' choices. Thus, role-playing is a useful strategy for implementing the Carnegie Foundation's call to 'engage the moral imaginations of students as they move toward professional practice'." Ann Southworth \& Catherine L. Fisk, Our Institutional Commitment to Teach About the Legal Profession, 1 UC IRVINE L. REV. 73, 80 (2011).

${ }^{78}$ James E. Moliterno, Legal Education, Experiential Education, and Professional Responsibility, 38 WM. \& MARY L. Rev. 71, 100 (1996). But see Jane B. Baron \& Richard K. Greenstein, Constructing the Field of Professional Responsibility, 15 Notre Dame J.L. ETHics \& PUB. POL'Y 37, 74 (2001) (arguing that "professional responsibility is widely understood to comprise distinctly legal materials, to address distinctly legal issues, and to coexist only contingently with other disciplines, include ethics").
} 
Given the experiential "bonus" that students gain in learning professional responsibility through a simulation, LRW is a logical choice that is already conveniently in place in first-year curricula.

\section{B. How We Addressed the Issue of Incidental Declarative Knowledge Acquisition Through Our Problem Design}

Our problem begins with a client who comes to the law firm thinking that she may have an employment discrimination claim. Students are asked to write a legal memorandum assessing whether the client can state a prima facie claim for "sexual orientation discrimination." Before they can begin writing, however, students are assigned the task of conducting research to determine whether the client has a claim. The law firm partner informs the students that their state has an "anti-discrimination statute" and that Title VII probably does not apply. The students must conduct research to confirm whether the partner is correct about Title VII and to determine the relevant state statute.

We chose to base the initial memo on an employment discrimination claim for several reasons. First, students have the opportunity to develop practical knowledge through a variety of research tasks. They must research both federal and state law, and they must conduct research in secondary sources, which in turn leads them to primary authority-statutes and case law. Students must learn to analyze a statute to determine the type of employment discrimination claim (or claims) that the client could potentially bring and what protected class(es) apply. Second, students have the opportunity to learn some civil rights law, declarative knowledge that is not typically gained in the first semester of law school. ${ }^{79}$ Third, the statutory cause of action is overlaid with a common law test that is set up in a straightforward four-element structure, which both provides the appropriate degree of complexity for the initial weeks of law school and also provides a simple example of the interplay between statutes and common law.

Once the research is complete, students are directed to write a legal memorandum focusing on whether the client can state a prima facie case for employment discrimination under the state statute. The memorandum is followed by individual student conferences. While conferences are ongoing, students are assigned to write a one-paragraph email ${ }^{80}$ informing their law firm partner whether the client's claim is timely. In conducting the research, students discover that the claim is no longer timely. The client, it turns out, had earlier asked a recently barred attorney friend of hers for advice on filing a discrimination suit and was given misleading information on how much time she had to file. The client then asks the firm to determine whether she can sue her friend for attorney malpractice. We

\footnotetext{
${ }^{79}$ See Liemer, supra note 61, describing why the LRW Director at Howard University School of Law chose to base an LRW assignment on employment discrimination law.

${ }^{80}$ Students are directed to write a single paradigm-structured paragraph in which they state their overall conclusion, identify the relevant rule (the applicable statute of limitations), explain the rule, and apply the law to the client's facts.
} 
chose to make the statute of limitations an issue because it provides a straightforward basis for the attorney malpractice claim. The students' final assignment for the fall semester is to write a legal memorandum assessing whether the client would likely prevail against the defendant-attorney in an attorney malpractice lawsuit. ${ }^{81}$

To prepare for writing the final memorandum, students must research a common law attorney malpractice claim. As in most jurisdictions, the claim requires a showing of duty, breach, and proximate causation of damages. The first and second elements of attorney malpractice invite discussion of the local rules of professional conduct, which establish the minimum standard of competence for attorneys who are licensed to practice law in the jurisdiction. The second incorporates the e-mail analysis about whether the statute of limitations is, in fact, different from what the client was told by her friend. And the third element incorporates the employment discrimination analysis from the first assignment of the semester.

Ultimately, the final memorandum incorporates all of the research and writing that the students have completed in the course to-date. Students appreciate this because they are not assigned any "busy work"-every research assignment and every writing assignment is part of their preparation for the final, graded assignment. ${ }^{82}$ And professors appreciate a course structure that allows multiple opportunities for the students to practice their developing skills and to reinforce the incidental declarative knowledge that the students have acquired.

In the second semester of LRW, students continue to work on the attorney malpractice claim. Students are divided into two groups: half of the class is assigned to represent the plaintiff and the other half of the class represents the defendant-attorney. The major writing assignment for the semester is a brief supporting their client's motion for summary judgment. ${ }^{83}$ The brief must conform to the state rules of court and a discussion of argumentation ethics is incorporated into the first week's lesson plan. ${ }^{84}$ At the end of the semester, each student argues the merits of the attorney malpractice claim in an oral argument on behalf of his or her client.

\footnotetext{
${ }^{81}$ Interim assignments include a preliminary citation list, draft question presented, and a 2000-word draft of the discussion of authority, followed by another round of individual student conferences.

${ }^{82}$ LRW professors at Temple do not grade interim assignments. The course grade is determined solely by each student's performance on the final writing assignment.

${ }^{83}$ Interim assignments in the spring semester include submitting a preliminary citation list, draft point headings, and a draft of the argument section of their brief. Individual conferences are held on the argument draft.

${ }^{84}$ Students learn that it is a violation of the ethical rules to intentionally disregard filing requirements or other obligations covered by court rules. Other ethical rules covered in the same lecture include: meritorious claims and contentions; candor towards the tribunal; fairness to opposing party and counsel; and truthfulness in statements to others. This discussion before students begin to form the arguments that will appear in their briefs helps them to understand how overzealous advocacy can lead to violations of ethical rules if they are not careful.
} 
By using a professional responsibility problem to teach LRW, we believe that we have advanced the pedagogical goals of the LRW program, while simultaneously addressing the problem of incidental declarative knowledge. The professional responsibility model works well by traditional measures of what makes a "good" subject for an LRW problem. First, it allows great flexibility in problem design. The assignment can be set in any jurisdiction, and the underlying claim can be literally anything that a lawyer might work on for a client. In addition, the problem design allows the professor to gradually increase the complexity of the coursework. The underlying claim allows professors to assign an easy early memo that then has new and more complicated facts overlaid. As the students move into persuasive writing during the second semester of the course, they have opportunities to develop policy-based arguments on behalf of their client as they think about the reasons underlying the ethical rules. ${ }^{85}$ And third, since legal malpractice is a tort, students frequently report that they feel more confident in both LRW and their Torts class as a result of this synergy between subject areas.

In the ways outlined above, using a professional responsibility problem in LRW and other simulation-based law courses can help the course designer create a problem in which all of the knowledge taught in the class-not just the practical knowledge-is taught deliberately. Of course, the model is not perfect. The occasional law student (more in some schools than others) may not intend on becoming a practicing attorney. For them, a professional responsibility problem will prove no more or less useful than one about, say, the Uniform Commercial Code. And not every student will be excited about a writing assignment that is essentially about legal ethics. Students learn best when they are highly interested in an assignment and excited about the underlying substantive area of law. ${ }^{86}$ Furthermore, Professional Responsibility is typically not a first-year course in most law schools. Therefore, students miss out on the synergistic effect of working on a legal writing assignment that is directly based on one of their first-year doctrinal subjects. ${ }^{87}$ On balance, however, we believe that our professional responsibility problem takes an important step in the process of addressing the incidental declarative knowledge problem in simulation-based law courses.

\section{CONCLUSION}

Law training must incorporate the how of lawyering as well as the what of legal doctrine. In truth, every law professor teaches some combination of formal doctrine (declarative knowledge) and skills (practical knowledge). For this reason, we reject the theorized separation between legal theory and legal doctrine. Instead, to better serve our students, we recommend giving greater attention during curriculum planning to both the declarative knowledge goals and the practical

\footnotetext{
${ }^{85}$ Professor Susan DeJarnatt chose bankruptcy law for her advanced legal writing course, partly because it is a policy-driven area of law. See DeJarnatt, supra note 20, at 59,60.

${ }^{86}$ Thrower, supra note 9 , at 38 . Professional responsibility, perhaps unfairly, is generally not seen as one of the sexier legal topics.

${ }^{87} \mathrm{Id}$. at 38-39.
} 
knowledge goals of the course. In other words, we suggest broadening our perspective to the entirety of knowledge production in the law school classroom, rather than just focusing on a particular area of law or a specific set of skills.

In particular, we encourage professors to give thoughtful consideration to the acquisition of that body of substantive, formalized knowledge gained during a simulation-based skills course. Although the how of lawyering is the primary focus, the substantive basis for the assignments should also be designed with purpose. Incorporating professional responsibility issues into an LRW course provides an excellent opportunity to purposefully introduce declarative knowledge that has lasting value to students, regardless of their career path. In addition to enhancing their professionalism training through experiential learning, students get to preview some of the issues that will arise in their required Professional Responsibility course. The professional responsibility model is practical for professors because it allows great flexibility in problem design. Finally, introducing professional responsibility issues early in our students' legal education serves the overall goals of producing lawyers who are knowledgeable, ethical, and skilled. 